\title{
How Ethnic Diversity Affects Tax Capacity: Evidence from Finland and Sweden
}

\author{
Xinyi LI \\ Shanghai Foreign Language School Affiliated to SISU, Shanghai 200000, China \\ Email:15221133650@163.com
}

\begin{abstract}
Compared to sheer economic scale, the answer to which country contains higher tax capacity may not be so apparent since tax capacity is a relatively complicated problem to measure. As a robust empirical regularity, tax capacity is proved to share a positive relationship with state capacity. To the extent that state capacity is in part affected by ethnic diversity, this essay argues that ethnic diversity should have a negative relationship with state capacity. s. The essay uses both theoretical elaboration and statistics to discover if ethnic diversity has a specific effect on the national tax capacity.
\end{abstract}

Keywords: tax capacity, state capacity, ethnic diversity

\section{LITERATURE REVIEW}

Tax is a compulsory contribution to state revenue, levied by the government on workers' income and business profits, or added to the cost of some goods, services, and transactions. (Oxford Dictionaries) The indispensability of tax enables the development of tax capacity. We define state capacity as the general ability for a state to manage the collection of tax.

\subsection{Tax capacity and state capacity}

Tax capacity shares a strong relationship with the economic development of a country. In more developed countries, firm size is large enough to enable effective third-party tax enforcement. (Kleven, Kreiner, and Saez,2009) Tax authority generally increases the frequency of tax audits and information cross-checking when firm size is large enough, say millions of euros. Moreover, as firm size increases, the counting system has to be designed with more complexity to evade tax by reporting less revenue, adding firms' difficulty creating information asymmetry between them and the tax authority. (Vitor Gaspar, Laura Jaramillo and Philippe Wingender, 2016)

On the other hand, economic constraints will limit the government's ability to impose a specific tax rate. Benedek and his fellows discover a negative association between foreign aid and domestic tax revenues, specifically in nations with weak government agencies, meaning large informal sectors in small-scale economies are inherently hard to tax. A more advanced, qualified tax system can efficiently reduce the loss of tax efficiency and elevate the GDP growth rate. The virtuous circle continues to work because the stability of tax revenue results in the smooth operation in public investment as well as government consumption, which is proposed by Ebeke and Ehrhart. Part of the reason is that more mandatory tax enforcement compels the degraded government to cut down the bribe, so the opportunity for private enterprise to participate in the market becomes more valuable.

In a nutshell, the state capacity is associated with the appearance of a stable economy, which means citizens can enjoy higher public good provisions and therefore have a higher willingness to pay the tax. Synchronously, working disciplines and punishment of abusing power in the tax collection department are efficient and transparent to the public. (Seidel, André, and Marcel Thum.,2016) This can also lead to higher public trust in tax system and tax collection costs.

\subsection{Ethnic diversity}

The economic decentralization is contributed by the high level of ethnic diversity, which means they share a positive relationship. It's worthy to notice that a high degree of fiscal decentralization has a negative correlation with corruption, a smaller informal sector, and efficient distribution of public goods. (Fisman \& Gatti, 2002) 
From another aspect, the effectiveness of aid shares a negative correlation with the level of decentralization and decreases the rate of inflation (Neyapti, 2004).

In terms of its relationship with taxation, Schumpeter emphasizes the importance of mutual effecting roles of taxation and historical origin, such as ethnic diversity, of the state in The Crisis of the Tax State. David Stasavage concludes the formation of democracy in Europe to be related to outside invasion then causes spliced, fragmented state structure to evolve into countries with the unique tax system. In concrete, the split of numerous kingdoms gradually evolved into different ethnicities. With the difference in living habits, working strength and respective group concentration, each ethnic has contributed to tax collection.

\section{METHODOLOGY}

\subsection{Model of state capacity}

Akhremenko A.S., Gorelsky I.E., and Melville A. Yu. created a model of state capacity. In their research, they placed different countries into respective ranks from high capacity to low capacity, having divided them into respective categories such as most developed countries, secondly developed countries, individual political systems and countries with oil and gas advantage.

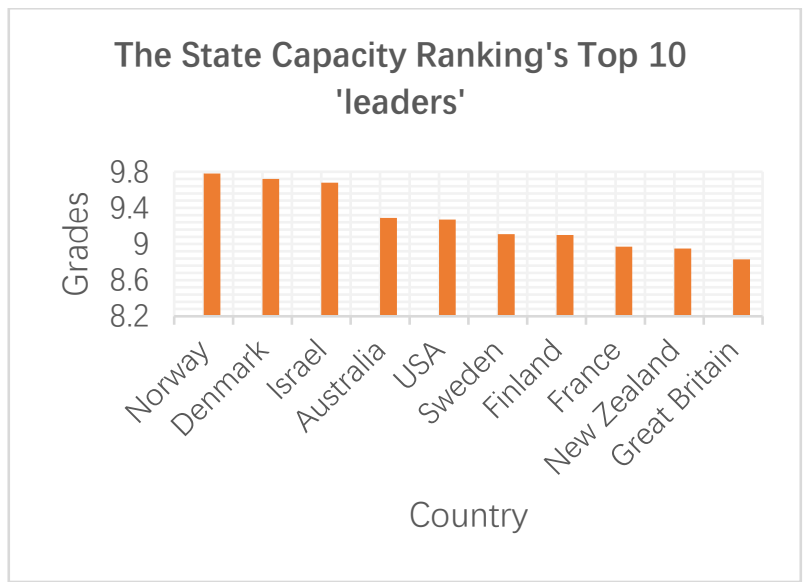

Figure 1. top ranking of state capacity

This graph is produced with data analyzed by Akhremenko A.S., Gorelsky I.E., and Melville A. Yu. Norway ranked the first as it had the highest score in the comprehensive survey conducted by HSE researchers of domestic institutions, economy, public services and the other factors.

Besley and Persson conclude three crucial dimensions of state capacity, which are fiscal capacity, legal capacity, and collective capacity.

The first factor is measured as the portion of income taxes in total revenue. The second factor represents a level of contract enforcement, which includes marketsupporting regulation, enforcement of government contracts, and protection of property rights. (Baunsgaard \& Keen,2010) The last factor is measured by school attainment as well as life expectancy by World Development Indicators.

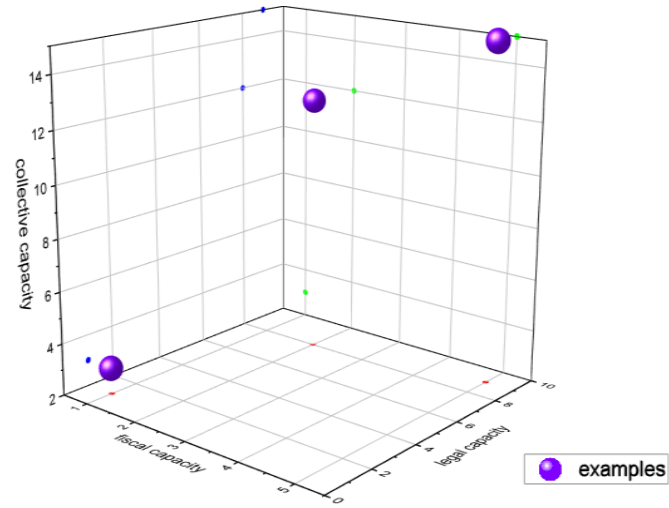

Figure 2. state capacity model

Besley and Persson (2014), in the three-dimension model of state capacity, points receiving the highest average scores represent the high-income countries, while the middle one represents middle income country and the lowest one lowincome country.

\subsection{Tax capacity measurement}

Tax capacity has been estimated by the actual tax collection, regional average per capita income, and gross regional product (GRP). However, the first one has a subtle drawback as the background of a country's economy produces extra elements to analyse in comparative researches measuring the effect of ethnicity. Average per capita income, also, includes tax resources of people outside the region. Overcounting the range of tax collection, Gross regional product (GRP) has the same drawback as well.

Tax revenue/GDP, or tax-to-GDP ratio, can be used to analyse the general tax capacity of a nation. Average GDP per capita reveals the essence of tax capacity. Here a World Bank Group dataset containing 264 countries' tax revenue/ GDP rate from 1990 to 2019 is employed. Considered as the symbolic index to show the trend of tax capacity, tax revenue/GDP rates will directly be used to measure in this article.

\subsection{Ethnic fractionalization}

Years before, the ethnic heterogeneity index has been considered not revealing the gradual adjustment in ethnic composition, as large changes occurred in the demographic overview of countries in the last decade. To measure the extent of ethnic diversity, this article chooses to measure a dataset from the Journal of Open Humanities Data, the Historical Index of Ethnic Fractionalization (HIEF). (Drazanova, Lenka, 2019) This ethnic fractionalization dataset is aiming at the longitudinal changes in ethnic diversity in 162 countries from 1945 to 2013. 
The data set uses the formula below to calculate the key index mentioned above. The formula shows the fractionalization in country $\mathrm{c}$ at a particular year(t), and $\mathrm{S}$ is the percentage of the ethnic population of the whole country. The result ranges from 0 to 1 , when all people belong to different folks or all belong to the same ethnic group.

$$
E F_{c t}=1-\sum_{i=1}^{n} S_{i}^{2}
$$

It has to be noticed that the basic composition of an ethnic group can change subtly, owing to the loss in wars and epidemic or other societal reasons. While in the attempt to discover its relationship with tax capacity, as we need a frequency from a macro view, the small adjustment can be ignored currently. Finland and Sweden are the objectives of the linear regression between fractionalization and tax capacity as they nearly rank the same in previous state capacity ranking.
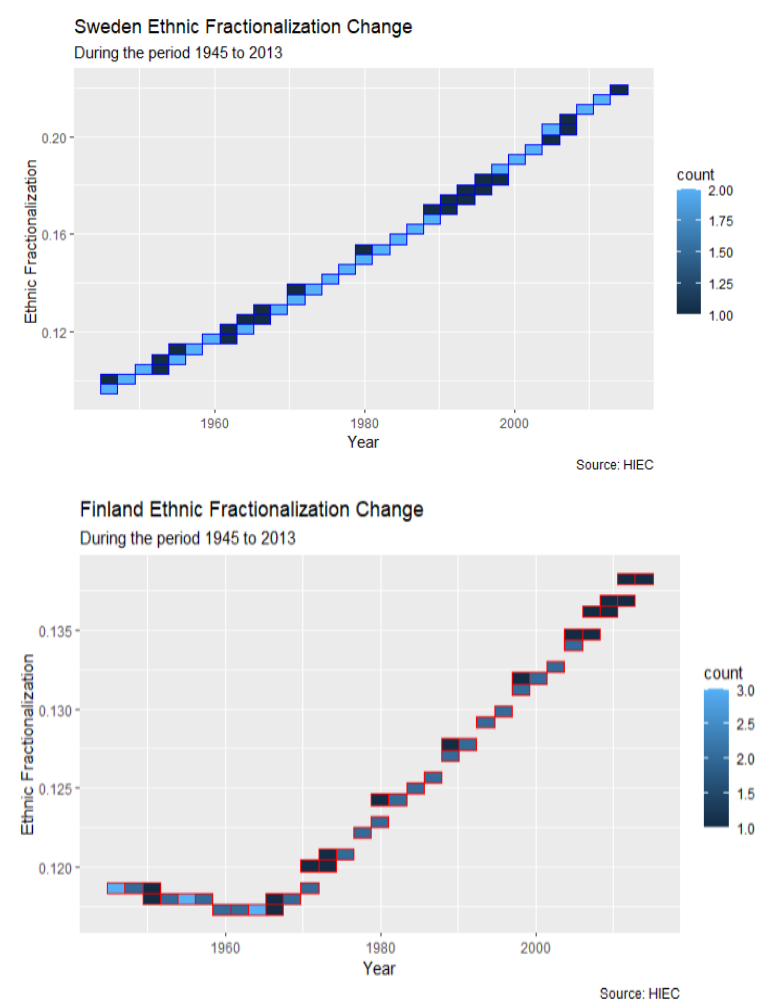

FIGURE 3, 4. Ethnic Fractionalization Change of Sweden and Finland from 1945 To 20133.

\section{REGRESSION OF ETHNIC FRACTIONALIZATION AND TAX CAPACITY}

As mentioned in the existed theory, economic efficiency and political inclusivity contribute to the construction of highly efficient political institutions. Because different ethnic group tends to have disparate preferences for public goods, countries, in turn, will be more decentralized to provide various kinds of public goods regionally. James Habyarimana et. al. concluded the reasons to be strategy selection and technology, which meant co-ethnics tended to give mutual support to each other more than non-co-ethnics did, and that coethnics linked with each other tightly in society, boasting stronger power to work and communicate as they share more common materials: languages, cultures and habits. As the common features of co-ethnic groups encourage them to work and communicate smoothly, successful collective actions, such as tax collection, will be carried out with less difficulty compared to groups with higher ethnic diversity.

Another interesting theory focuses on the identity of the ethnic group itself. People may be willing to pay for public goods if they regard co-ethnics to be the ones receiving benefit from these. When other ethnic groups experience improvements, members in this group may think of themselves as not derived benefits. (Tajfel 1974) This psychological trigger provides continuous power that co-ethnic groups call for innovations and improvements on tax usage in their society, shifting any improper use of tax to efficient and practical tax usage, such as building public facilities or improving education. Not to mention that they would be more willing to pay efforts in this goal, counting for the high rates of public goods distribution in this kind of community.

Cost of governing augments along with the size of a country. Decreasing per capita cost of public goods and depressed economies scale appears when taxation beyond a certain level. The measure of satisfying a diverse population is costly and can result in secession or civil conflict (Alesina \& Spolaore, 2000). Therefore, decentralization is beneficial since it can improve the efficiency of political institutions.

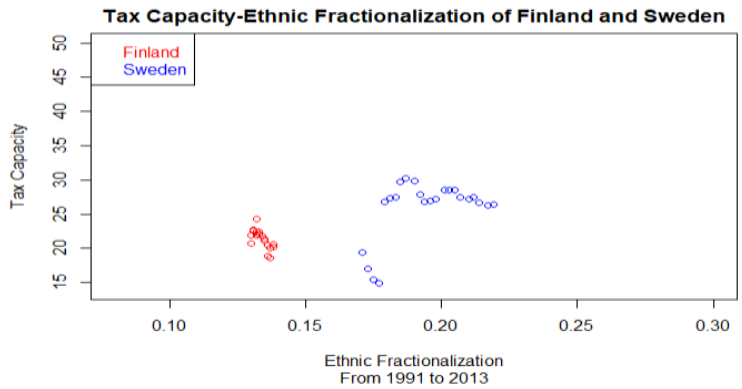

FIGURE 5. Correlation between ethnic fractionalization and tax capacity

For both countries, higher ethnic diversity is associated with lower tax capacity. It's noteworthy that Sweden has experienced a chasm in tax capacity owing to societal changes, but still, the tendency of negative relationship is able to tell.

While the profound reason behind this seemingly astonishing fact still needs more observation. In the future, to figure out whether the fact has to do with geographical feature, we will apply more between-country researches. 


\section{CONCLUSIONS}

Having been proved to share a positive correlation with state capacity, which is measured by three dimensions ---fiscal capacity ensuring regular market working, legal capacity protecting privacy rights, and public distribution supplying public goods, tax capacity is a complicated demonstration of other social factors which we do not necessarily consider to be related. Ethnic diversity, tested by ethnic fractionalization, reveals how decentralization adds difficulty in governments' collecting consolidated tax. As much ethnic diversity means more opposition against the policies of other ethnicities, countries boasting numerous nationalities spend excessive economic and political resources on negotiation to raise the efficiency of collection, such as welfare to the minority. Pay more attention to social factors when researchers are trying to solve puzzles of economic phenomena can be inspiring, as well as meaningful. It teaches all men who are devoted to being economists, sociologists or policymakers the motto to contemplate the permanent subject of economy, which is people.

\section{REFERENCES}

[1] Kleven, Henrik Jacobsen, et al. That Full Credit, Including Notice, Is given to the Source. The Optimal Income Taxation of Couples. no. 2, 2009, pp. 537-60.

[2] Crivelli, Ernesto, et al. "Foreign Aid and Revenue: Still a Crowding Out Effect?" Finanzarchiv Public Finance Analysis, vol. 70, no. 1, 2012, p.

[3] Besley, Timothy, and Torsten Persson. "The Causes and Consequences of Development Clusters: State Capacity, Peace, and Income." Annual Review of Economics, vol. 6, no. 1, Aug. 2014, pp. 927-49. DOI.org (Crossref), doi:10.1146/annureveconomics-080213-041128.

[4] Seidel, André, and Marcel Thum. "Tax Evasion, Corruption and Market Entry." Scottish Journal of Political Economy, vol. 63, no. 4, 2016, pp. 377-98.

[5] Christian, et al. "Editor's Choice: Tax Revenue Instability in Sub-Saharan Africa: Consequences and Remedies." J Afr Econ, 2012.

[6] Schumpeter, Joseph A. The Crisis of the Tax State BT - Joseph A. Schumpeter: The Economics and Sociology of Capitalism. 1991.

[7] Gaspar, Vitor, et al. "Tax Capacity and Growth: Is There a Tipping Point?" IMF Working Papers, vol. 16, no. 234, 2016, p. 1. DOI.org (Crossref), doi:10.5089/9781475558173.001.

[8] Miguel, Edward, and Mary Kay Gugerty. "Ethnic Diversity, Social Sanctions, and Public Goods in
Kenya." Journal of Public Economics, vol. 89, no. 11-12, 2005, pp. 2325-68.

[9] Raymond, et al. "Decentralization and Corruption: Evidence across Countries." Journal of Public Economics, 2002.

[10] Habyarimana, James, et al. Why Does Ethnic Diversity Undermine Public Goods Provision? An Experimental Approach. p. 39.

[11] Hainmueller, Jens, and Michael J. Hiscox. "Attitudes toward Highly Skilled and Low-Skilled Immigration: Evidence from a Survey Experiment." American Political Science Review, vol. 104, no. 1, 2010, p. 24.

[12] Nyapti, Bilin. "Trends in Workers' Remittances : A Worldwide Overview." Emerging Markets Finance \& Trade, vol. 40, no. 2, 2004, pp. 83-90.

[13] Wacziarg, Romain, et al. "Economic Integration and Political Disintegration." Scholarly Articles, 2000.

[14] Tajfel, and H. "Social Identity and Intergroup Behaviour." Social Science Information, vol. 13, no. 2, 1974, pp. 65-93.

[15] Drazanova, Lenka. "Introducing the Historical Index of Ethnic Fractionalization (HIEF) Dataset: Accounting for Longitudinal Changes in Ethnic Diversity." Journal of Open Humanities Data, vol. 6, Sept. 2020, p. 6. DOI.org (Crossref), doi:10.5334/johd.16.

[16] Stasavage, David. "Representation and Consent: Why They Arose in Europe and Not Elsewhere." Annual Review of Political Science, vol. 19, no. 1, May 2016, pp. 145-62. DOI.org (Crossref), doi:10.1146/annurev-polisci-043014-105648.

[17] Akhremenko A.S., Gorelsky I.E., et al. "How and why to measure and compare the state wealth of different countries of the world? Experience of empirical research". Polis. Political research. 2019, pp. 49-68, doi:10.17976/jpps/2019.03.04. 